\title{
Activation of Mitochondrial Functions by Malotilate in Relation to Accelerated Liver Regeneration in Partially Hepatectomized Rats
}

\author{
Yoshimi NIWANO, Shigeo KONAKA, Matazaemon UCHIDA \\ and Tatsuyoshi SUGIMOTO \\ Institute of Life Science Research. Nihon Nohyaku Co., Ltd., \\ Kawachi-Nagano, Osaka 586, Japan \\ Accepted September 6. 1986
}

\begin{abstract}
Malotilate was orally administered to rats at a dose of $100 \mathrm{mg} / \mathrm{kg} 2 \mathrm{hr}$ after partial hepatectomy. Mitochondrial state 3 respiration of the liver increased significantly from $23.4 \mathrm{nmol} / \mathrm{min} / \mathrm{mg}$ protein in the control rats to $29.3 \mathrm{nmol} / \mathrm{min} /$ $\mathrm{mg}$ protein in the rats administered with malotilate at $3 \mathrm{hr}$ after the hepatectomy ( $1 \mathrm{hr}$ after the administration). The administration also resulted in higher tendencies in the respiratory control ratio after 3,6 or $20 \mathrm{hr}(1,4$ or $18 \mathrm{hr}$ after the administration) than in the control rats. Although partial hepatectomy made hepatic ATP concentration remarkably low, it gradually increased (from $1.53 \mathrm{kmol} / \mathrm{g}$ liver after $3 \mathrm{hr}$ ) to a level of $2.03 / \mathrm{mol} / \mathrm{g}$ liver after $20 \mathrm{hr}$ in the rats administered with malotilate. No increase in ATP concentration was observed in the control rats. Correspondingly. the adenylate energy charge also showed higher tendencies in the malotilate administered rats. From these result, it is supposed that malotilate activates the mitochondrial functions which results in the increases of ATP concentration and adenylate energy charge. These changes in energy metabolism can be associated with accelerated regeneration of the liver by malotilate.
\end{abstract}

\section{Malotilate (Diisopropyl 1,3-dithiol-2-} ylidenemalonate) is a drug for liver cirrhosis (1). The drug has been shown to enhance protein synthesis in normal rat liver (2) and to induce characteristically microsomal cytochrome $b_{5}$ rather than P-450 $(3,4)$. Intraperitoneal administration of malotilate can facilitate the liver regeneration in cirrhotic rats (5). Recently. we have found that an oral administration of malotilate facilitates liver regeneration in the rats (6). Portal factors such as insulin and glucagon also accelerate liver regeneration (7-9). Like insulin (10). therefore, malotilate may stimulate mitochondrial oxidative phosphorylation. This study was designed to examine the effect of malotilate on the mitochondrial function in relation to hepatic adenine nucleotide concentrations (and adenylate energy charge) of partially hepatectomized rats.

\section{Materials and Methods}

Chemicals, animals and partial hepatectomy: Chemicals and animals used in this experiment, the procedures for partial or sham hepatectomy, and the administration of malotilate and/or its vehicle were the same as those described in our previous paper (6).

Analysis of mitochondrial functions: Liver mitochondrial functions were measured 3,6 or $20 \mathrm{hr}$ after the partial or sham hepatectomy (1, 4 or $18 \mathrm{hr}$ after the administration). Rat liver mitochondria was prepared by homogenization of rat liver followed by differential centrifugation as described by Hogeboom et al. (11) with minor modifications. The mitochondrial pellet was washed once, suspended in the medium containing $0.25 \mathrm{M}$ sucrose, $0.1 \%$ bovine serum albumin and $3 \mathrm{mM}$ Tris- $\mathrm{HCl}$ buffer $(\mathrm{pH}$ 
7.4). The obtained mitochondrial fraction $(0.2$ $\mathrm{ml}$ ) was added into the reaction medium (3 $\mathrm{ml}$ ) containing $0.25 \mathrm{M}$ sucrose, $0.1 \%$ bovine serum albumin and $10 \mathrm{mM}$ potassium phosphate buffer ( $\mathrm{pH}$ 7.4). Six $/$ mol of succinate and $0.25 \mu \mathrm{mol}$ of ADP were then added. Mitochondrial state 3 respiration, respiratory control ratio (RCR) and $A D P / O$ $(P / O)$ ratio were measured with an oxygen monitor (Rank Brother Co., Ltd., England). Mitochondrial protein was measured according to the method of Lowry et al. (12).

Analysis of adenine nucleotides: Liver adenine nucleotide concentrations and adenylate energy charge were measured at 3 . 6 or $20 \mathrm{hr}$ after the partial hepatectomy (1, 4 or $18 \mathrm{hr}$ after the administration). Under ether anesthesia, the liver was removed with pre-cooled aluminium clamps, pulverized in liquid nitrogen and homogenized with $0.6 \mathrm{~N}$ perchloric acid. After centrifugation $\left(400 \times \mathrm{g}\right.$ for $10 \mathrm{~min}$ at $4^{\circ} \mathrm{C}$ ), the supernatant of the homogenate was neutralized with 0.54 $\mathrm{N} \mathrm{KOH}$ and diluted with $0.2 \mathrm{M}$ potassium phosphate buffer ( $\mathrm{pH}$ 7.0). Adenine nucleotide concentrations were then measured with HPLC (Column: TSK-gel DEAE-2SW, Detector: SPD-2A, Pump: LC30). Adenylate energy charge was calculated according to the equation proposed by Atkinson (13).

Statistical analysis: The significance of the difference between two groups was assessed by Student's $t$-test.

\section{Results}

Mitochondrial functions in liver: The state 3 respiration, RCR and $\mathrm{P} / \mathrm{O}$ ratio of the mitochondrial fraction in the liver of partially or sham hepatectomized rats are summarized in Fig. 1. The P/O ratio was around 2.0 in all the groups. The state 3 respiration at $6 \mathrm{hr}$ after and the RCR at 3 or $6 \mathrm{hr}$ after the hepatectomy showed a tendency to be higher in the sham operated rats administered with malotilate than in the control rats. Therefore, malotilate seems to activate hepatic mitochondrial functions in the sham operated rats. The effect of malotilate was more obvious in the partially hepatectomized rats than in the sham operated rats. The state 3 respiration of the liver mitochondrial fraction significantly increased from $23.4 \mathrm{nmol} / \mathrm{min} / \mathrm{mg}$ protein in the control to $29.4 \mathrm{nmol} / \mathrm{min} / \mathrm{mg}$ protein in the malotilate administered group with partial hepatectomy after $3 \mathrm{hr}$. The RCR in the partially hepatectomized rats tended to be increased after 3 or $6 \mathrm{hr}$, and it was significantly increased after $20 \mathrm{hr}$ by the administration of malotilate. The $\mathrm{P} / \mathrm{O}$ ratio in the partially hepatectomized rats also tended to be increased by the administration after 6 or $20 \mathrm{hr}$.

Adenine nucleotide concentrations in liver: Liver adenine nucleotide concentrations and adenylate energy charge in the partially or sham hepatectomized rats are summarized in Table 1. In the partially hepatectomized rats, liver AMP concentration tended to be higher, but ATP concentration and adenylate energy charge were lower than those in the sham operated rats throughout the experiment. By the administration of malotilate to the partially hepatectomized rats, the AMP concentration was observed to become lower $(0.49,0.54$ or $0.62 \mu \mathrm{mol} / \mathrm{g}$ liver in the control and 0.40 , 0.34 or $0.45 \mathrm{\mu mol} / \mathrm{g}$ liver in the malotilate administered group at 3.6 or $20 \mathrm{hr}$ after the hepatectomy, respectively). Although the ATP concentration in the partially hepatectomized control rats remained almost unchanged $(1.63,1.77$ or $1.40 \mu \mathrm{mol} / \mathrm{g}$ liver at 3,6 or $20 \mathrm{hr}$, respectively). malotilate administration increased it $(2.03 \mathrm{\mu mol} / \mathrm{g}$ liver after $20 \mathrm{hr}$ ) finally to a level similar to that of sham operated rats. The adenylate energy charge also remained lower after $3 \mathrm{hr}$ in the malotilate administered group, but it then recovered to the same level as that in the sham operated rats 6 or $20 \mathrm{hr}$ after the hepatectomy. Thus, these data show that malotilate elevates ATP concentration and adenylate energy charge in the partially hepatectomized rats.

\section{Discussion}

Malotilate has recently been shown to accelerate liver regeneration in rats (6). The present study. where the experimental conditions were similar to those described in our previous study (6), revealed that mitochondrial functions. ATP concentration and adenylate energy charge in the liver: of partially hepatectomized rats tended to be 


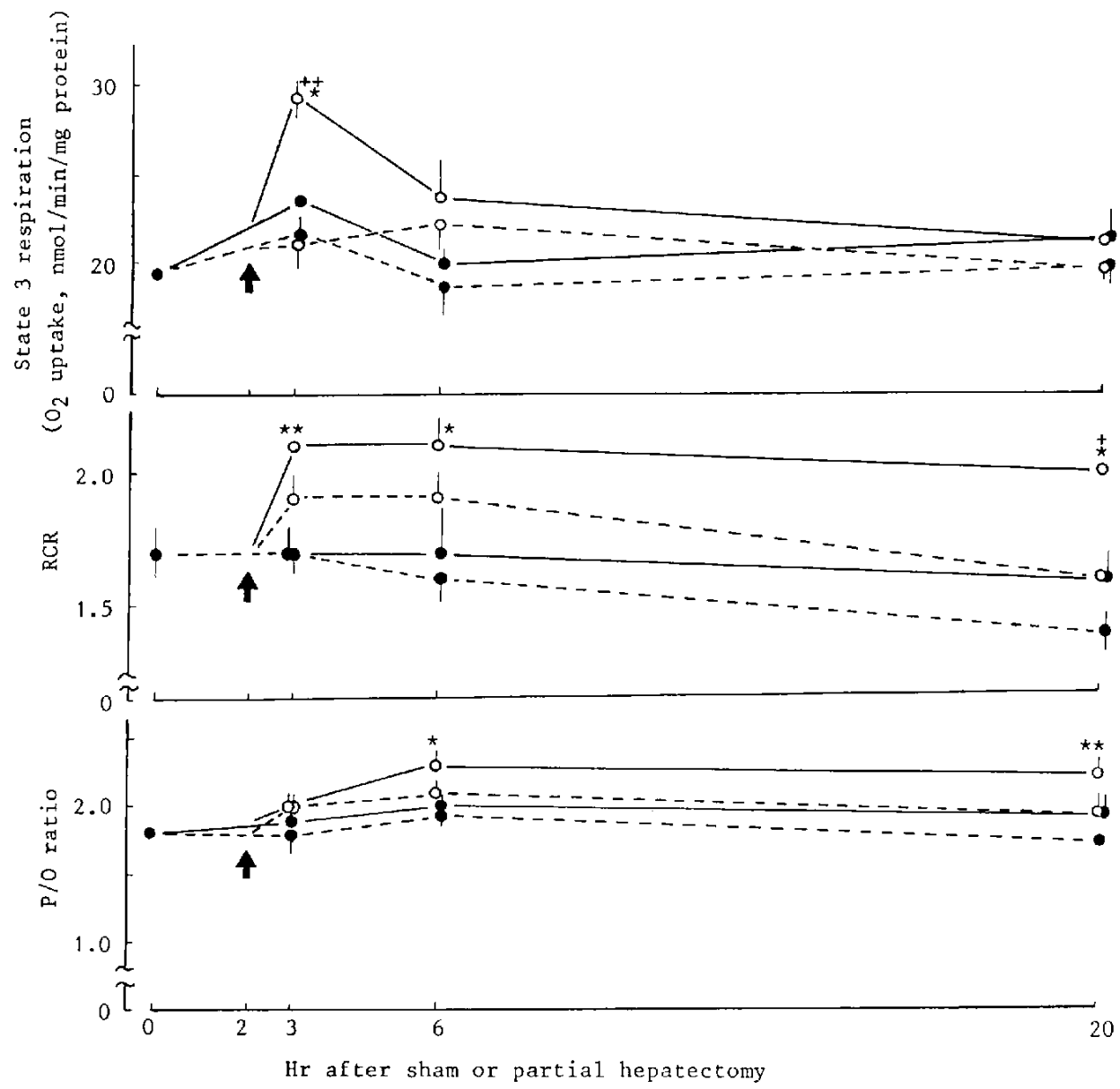

Fig. 1. Liver mitochondrial state 3 respiration, respiratory control ratio (RCR) and $A D P / O(P / O)$ ratio in the sham or partially hepatectomized rats administered with malotilate and/or its vehicle. Keys: ---- Sham hepatectomized rats administered with $2 \%$ gum arabic solution, $\bigcirc-$-.- $^{-}$Sham hepatectomized rats administered with malotilate, - Partially hepatectomized rats administered with $2 \%$ gum arabic solution, $\bigcirc-O$ Partially hepatectomized rats administered with malotilate. $\star P<0.05$ and $\star \star P<0.01$ vs. sham hepatectomized rats administered with $2 \%$ gum arabic solution, $+P<0.05$ and $++P<0.01$ vs. partially hepatectomized rats administered with $2 \%$ gum arabic solution. $\uparrow$ Malotilate $(100 \mathrm{mg} / \mathrm{kg})$ and/or its vehicle administration. Each circle and vertical bar represents the mean and standard error of 3 animals, respectively.

elevated or were significantly elevated by malotilate administration at 3-20 hr after the hepatectomy (Fig. 1 and Table 1). Therefore, the elevation of liver ATP concentration and adenylate energy charge seems to be due to the activation of mitochondrial functions by malotilate. The action of malotilate is considered to contribute to the acceleration of liver regeneration and such an acceleration has already been observed $24 \mathrm{hr}$ after the hepatectomy (6). As reported by Kamiyama et al. (14), the mitochondrial phosphorylative activity increases adaptively to provide energy for enhanced biosynthetic ATP-utilizing reactions at an early stage in the regenerating process of the liver. The present study suggested that malotilate available to hepatocytes makes mitochondria activate providing more energy for the regenerating process. 
Table 1. Liver adenine nucleotide concentrations and adenylate energy charge in the partially or sham hepatectomized rats after malotilate administration

\begin{tabular}{|c|c|c|c|c|c|c|c|}
\hline \multirow{2}{*}{$\begin{array}{l}\text { Hours after } \\
\text { sham or partial } \\
\text { hepatectomy }\end{array}$} & \multirow{2}{*}{$\begin{array}{l}\text { Hepatec- } \\
\text { tomy }\end{array}$} & \multirow{2}{*}{$\begin{array}{l}\text { Maloti- } \\
\text { late }\end{array}$} & \multirow{2}{*}{ AMP } & $A D P$ & ATP & \multirow[t]{2}{*}{ TANa } & \multirow{2}{*}{$\mathrm{AECb}$} \\
\hline & & & & \multicolumn{2}{|c|}{ ( $\mu \mathrm{mol} / \mathrm{g}$ liver) } & & \\
\hline \multirow[t]{2}{*}{0} & 一 & - & $0.34 \pm 0.04$ & $1.04 \pm 0.08$ & $2.13 \pm 0.12$ & $3.52 \pm 0.05$ & $0.76 \pm 0.02$ \\
\hline & Sham & - & $0.37 \pm 0.03$ & $1.18 \pm 0.09$ & $2.43 \pm 0.12$ & $3.98 \pm 0.06$ & $0.76 \pm 0.02$ \\
\hline \multirow[t]{2}{*}{3} & Partial & - & $0.49 \pm 0.10$ & $1.23 \pm 0.14$ & $1.63 \pm 0.14^{* *}$ & $3.36 \pm 0.13$ & $0.67 \pm 0.04$ \\
\hline & Partial & + & $0.40 \pm 0.03$ & $1.40 \pm 0.12$ & $1.53 \pm 0.15^{* *}$ & $3.34 \pm 0.13$ & $0.67 \pm 0.02^{*}$ \\
\hline \multirow{3}{*}{6} & Sham & - & $0.35 \pm 0.04$ & $1.04 \pm 0.08$ & $2.18 \pm 0.17$ & $3.56 \pm 0.22$ & $0.76 \pm 0.02$ \\
\hline & Partial & - & $0.54 \pm 0.09$ & $1.25 \pm 0.06$ & $1.77 \pm 0.25$ & $3.57 \pm 0.12$ & $0.67 \pm 0.04$ \\
\hline & Partial & + & $0.34 \pm 0.09$ & $1.17 \pm 0.23$ & $1.75 \pm 0.11$ & $3.26 \pm 0.35$ & $0.73 \pm 0.03$ \\
\hline \multirow{3}{*}{20} & Sham & - & $0.48 \pm 0.06$ & $1.15 \pm 0.10$ & $1.97 \pm 0.13$ & $3.59 \pm 0.13$ & $0.71 \pm 0.02$ \\
\hline & Partial & - & $0.62 \pm 0.06$ & $1.29 \pm 0.15$ & $1.40 \pm 0.15^{*}$ & $3.32 \pm 0.08$ & $0.62 \pm 0.03^{*}$ \\
\hline & Partial & + & $0.45 \pm 0.05$ & $1.42 \pm 0.04^{*}$ & $2.03 \pm 0.14^{+}$ & $3.91 \pm 0.12^{++}$ & $0.70 \pm 0.02$ \\
\hline
\end{tabular}

a TAN stands for total adenine nucleotides. $\mathrm{b}$ AEC stands for adenylate energy charge. Each value represents the mean \pm standard error of 5 animals. Significant difference from sham hepatectomized rats, ${ }^{*} P<0.05$ and ${ }^{* *} P<0.01$. Significant difference from partial hepatectomized rats, $+P<0.05$ and ${ }^{++} \mathrm{P}<0.01$. Malotilate or its vehicle was administered $2 \mathrm{hr}$ after sham or partial hepatectomy.

\section{References}

1 Oda, T. and Tygstrup, N.: Hepatotrophic agent malotilate. Proceedings of a symposium on malotilate held at the 7 th World Congress of Gastroenterology, p. 54-76, Excerpta Medica, Amsterdam, Princeton, Geneva and Tokyo (1983)

2 Imaizumi, Y., Katoh, M., Sugimoto, T. and Kasai, T.: Effect of malotilate (diisopropyl 1,3dithiol-2-ylidenemalonate) on the protein synthesis in rat liver. Japan. J. Pharmacol. 32, 369375 (1982)

3 Katoh, M., Kitada, M., Satoh, T., Kitagawa, H., Sugimoto, T. and Kasai, T.: Effect of diisopropyl 1.3-dithiol-2-ylidenemalonate on microsomal electron transport system in rat liver. J. Pharmacobiodyn. 3, 261-263 (1980)

4 Katoh, M., Kitada, M., Satoh, T., Kitagawa, H., Sugimoto, T. and Kasai, T.: Further studies on the in vivo effect of diisopropyl 1,3-dithiol-2ylidenemalonate (NKK-105) on the liver microsomal drug oxidation system in rats. Biochem. Pharmacol. 30, 2759-2765 (1981)

5 Igarashi, S., Hatahara, T. and Oda, T.: Effect of diisopropyl 1,3-dithiol-2-ylidenemalonate (NKK105) on cell proliferation and protein metabolism in the liver of rat and mouse. Acta Hepatol. Japon. 21, 1-7 (1980) (in Japanese)

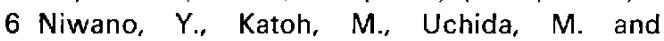
Sugimoto, T.: Acceleration of liver regeneration by malotilate in partially hepatectomized rats. Japan. J. Pharmacol. 40, 411-415 (1986)

7 Bucher, N.L. and Weir, G.C.: Insulin, glucagon, liver regeneration, and DNA synthesis. Metabolism 25, 1423-1425 (1976)

8 Leffert, H.L., Koch, K.L., Moran, T. and Rubalcave, B.: Hormonal control of rat liver regeneration. Gastroenterology 76, 1470-1482 (1979)

9 Takatsuki, K., Fujisawa, K., Hayashi, Y., Ota, Y., Torii, M., Mishiro, S., Ogata, I., Sakuma, A., Oka, $\mathrm{H}$. and Oda, T.: Acceleration of DNA synthesis in post-hepatectomized regenerating liver of normal rat by insulin and glucagon. Life Sci. 29, 2609-2615 (1981)

10 Ozawa, K., Yamaoka, Y., Nanbu, H. and Honjo, 1.: Insulin as the primary factor governing changes in mitochondrial metabolism leading to liver regeneration and atrophy. Am. J. Surg. 127, 669-675 (1974)

11 Hogeboom, G.H., Schneider, W.C. and Pallade, G.E.: Cytochemical studies of mammalian tissues. I. Isolation of intact mitochondria from rat liver: some biochemical properties of mitochondria and submicroscopic particulate material. J. Biol. Chem. 172, 619-635 (1948)

12 Lowry, O.H., Rosebrough, N.J., Fair, A.L. and Randall, R.J.: Protein measurement with Folin phenol reagent. J. Biol. Chem. 193, 265-275 (1951)

13 Atkinson, D.E.: The energy charge of the 
adenylate pool as a regulatory parameter, interaction with feed back modifiers. Biochemistry 7, 4030-4034 (1968)

14 Kamiyama, Y., Ozawa, K. and Honjo, 1.: Changes in mitochondrial phosphorylative activity and adenylate energy charge of regenerating rabbit liver. J. Biochem. 80, 875-881 (1976) 